\title{
Pretreatment of Palm Oil Mill Effluent (POME) Using Lipase and Xylanase to Improve Biogas Production
}

\author{
O M Shafwah ${ }^{1}$, D Suhendar ${ }^{2, *}$ and S Hudiyono ${ }^{1}$ \\ ${ }^{1}$ Department of Chemistry, University of Indonesia Kampus UI, Pondok Cina, Beji, Pondok Cina, Kecamatan Beji, \\ Kota Depok, Jawa Barat 16424, Indonesia. \\ ${ }^{2}$ Agro Industrial and Biomedical Technology Development Laboratory, Agency for The Assessment and Application \\ of Technology, Tangerang Selatan. 15314 \\ *Corresponding author. Email: dadang.suhendar@bppt.go.id
}

\begin{abstract}
The production process at biogas reactors from Palm Oil Mill Effluent (POME) often faces problems due to limited hydrolysis rates. This limitation occurs due to the formation of mud and lumps which reduce the effective volume of the biogas digester and reduce the potential for biogas produced. The sludge and lumps produced come from the high content and fiber present in the POME. Various treatments have been made such as manual extraction or mechanical stirring or by turbulence through strong fluid pumping. However, these treatments require additional tools, human resources, and energy so that the production process costs continue to increase. As an alternative, the use of lipase and xylanase is promising alternative for pretreatment that can minimize the content of hemicellulose and oil or fat in POME. Lipase can hydrolyze oil and grease into short-chain fatty acids, while xylanase can hydrolyze hemicellulose into its monomer, thus facilitating biogas production. In this study, it was proven that pretreatment with xylanase and lipase was able to reduce total suspended solid (TSS) by $49.21 \%$; total solid (TS) by $34.52 \%$ and reducing sugar by $44.37 \%$. Besides, it could reduce oil and grease $(83.53 \%)$ at a concentration of $4 \%$, increase biogas production by $52.17 \%$, and remove chemical oxygen demand (COD) by $49.7 \%$.
\end{abstract}

Keywords: Biogas, Lipase, Xylanase, POME.

\section{INTRODUCTION}

During operation to produce crude palm oil (CPO) and palm kernel, the palm oil industry also produces waste. Each ton of CPO emits approximately 2.5 tons of palm oil mill effluent (POME), 0.9 tons of empty fruit bunches (EFB), 0.6 tons of mesocarp fibers, and 0.27 tons of shells[1]. POME is waste water highly polluting, and causing considerable soil damage and water quality when it is disposed to the environment without treatment $[2,3]$. The high content of chemical oxygen demand (COD) and biochemical oxygen demand (BOD) in POME can be utilized and converted into methane. In other words, POME can be used as a source to produce biogas[4]. The conversion of organic matter in POME to methane is one of the potentials and useful processing methods, because methane is a renewable energy source that has important value.
The most widely method used to convert POME to biogas is anaerobic decomposition. Anaerobic decomposition is a biological method that utilizes microorganisms to degrade complex organic compounds without the use of oxygen. This method is considered to be environmentally friendly, and produces methane gas that can be utilized as POME content consisting of $26.72 \%$ lignin, $23.21 \%$ hemicellulose, and $38.36 \%$ cellulose[4]. In the process of degrading POME into methane, carbon dioxide, and water, the sequences involved are hydrolysis, acidogenesis, acetogenesis, and methanogenesis[5]. Based on its function, hydrolysis is the main step and known as the important step, since the complete degradation of complex organic matter takes time. Therefore, this study aims to conduct POME pretreatment to increase the hydrolysis using lipase and xylanase. Lipase plays an important role in hydrolyzing long chain triglyceride and transforming it into short 
chain compound as free fatty acids and glycerol $[6,7]$. Meanwhile, xylanase is known to hydrolyze hemicellulose into reduced sugar to accelerate hydrolytic reaction and increase biogas production [8].

\section{MATERIAL AND METHODS}

\subsection{Equipment and Chemicals}

The equipment used are thermometer, UV-Vis spectrophotometer, shaker, incubator, vortex, porcelain cup, oven, separating funnel, desiccator, water bath, distillation flask, and centrifuge. The main sample is Palm Oil Mill Effluent (POME) from PKS Cikasungka Bogor under PTPN VIII. Raw materials used to support the study research include Birchwood xylan substrate, p-nitrophenyl palmitate (p-NPP) substrate, 3,5dinitrosalicylic acid reagent (DNS), ethanol, methanol, Sodium hydroxide $(\mathrm{NaOH}) 0.05 \mathrm{M}$, n-hexane, sodium sulfate anhydrous $\left(\mathrm{Na}_{2} \mathrm{SO}_{4}\right)$, indicator phenolphthalein, lipase, xylanase, milli-Q, and potassium hydrogen phthalate.

\subsection{Lipase Activity Test}

A total of $5 \mathrm{~mL}$ substrate mixture $(25 \%$ olive oil + $1.5 \%$ PVA (Polyvinyl Alcohol) + water) was put into $100 \mathrm{~mL}$ Erlenmeyer, then added with $4 \mathrm{~mL}$ buffer tris $\mathrm{HCl} 0.05 \mathrm{M} \mathrm{pH} 6$ and $1 \mathrm{~mL}$ lipase production by Aspergillus niger. The solution was incubated for 20 minutes at $37^{\circ} \mathrm{C}$. After incubation, the sample was added with $5 \mathrm{~mL}$ methanol and 2 drops of the indicator phenolphthalein followed by titration using sodium hydroxide of $0.05 \mathrm{M}$.

\subsection{Xylanase Activity Test}

Mixed solution containing buffer $(50 \mathrm{mM}$ buffer citrate) and $0.05 \mathrm{~mL}$ of xylanase were added with 0.45 $\mathrm{mL}$ of Birchwood xylan substrate; the mixed solution was shaken until homogeneous and incubated at $60^{\circ} \mathrm{C}$ for 5 minutes. Furthermore, the DNS reagent (Dinitrosalicylic acid) of $0.75 \mathrm{~mL}$ was added to cease the reaction; the mixed solution was heated for 5 minutes in the waterbath and cooled in $28^{\circ} \mathrm{C}$ for 5 minutes, was added with $0.25 \mathrm{~mL}$ of water and shaken with vortex. Furthermore, the absorbance measurement was carried out at $540 \mathrm{~nm}$ with a UV-Vis spectrophotometer.

\subsection{Pretreatment POME with Lipase and Xylanase}

A total of $100 \mathrm{~mL}$ POME was added to each Erlenmeyer flask which then added with 2 variations of the concentration of lipase and xylanase solutions consisting of concentration at 2 and $4 \%$, respectively. The Erlenmeyer is tightly closed to prevent evaporation during the hydrolysis process. Furthermore, the Erlenmeyer containing the sample and enzyme was incubated for $0,24,48,72$ and 96 hours at a speed of $150 \mathrm{rpm}$. Analysis was carried out in terms of total suspended solid, total solid, reduced sugar, oil and grease every 24 hours.

\subsection{Total Suspended Solid Analysis}

Filter paper was washed twice with distilled water; while the sample (POME) was stirred using a magnetic stirrer to obtain a homogeneous sample. A volume of 2 $\mathrm{mL}$ was taken using pipette into the vacuum equipment coated by filter paper and vacuumed until the sample was evaporated into the vacuum flask. The filter paper containing the sample was transferred to a weighing container (cup) that had been weighed. The cup containing the sample was put into the oven for 1 hour at $105^{\circ} \mathrm{C}$. The dried residue was cooled in the desiccator to balance the temperature then weighed to obtain constant weight [9].

\subsection{Chemical Oxygen Demand}

The sample of $625 \mu \mathrm{L}$ was put into the vial bottle containing COD reagent of $375 \mu \mathrm{L}$ digestive solution and $875 \mu \mathrm{L}$ sulfuric acid solution. Furthermore, the vial was heated at $150^{\circ} \mathrm{C}$ for 2 hours, then removed and cooled to obtain $28^{\circ} \mathrm{C}$. The sample was measured at a wavelength of $620 \mathrm{~nm}$ utilizing UV-Vis spectrophotometer [10].

\subsection{Oil and Fat Analysis}

The sample of $15 \mathrm{~mL}$ was put into a separating funnel, added drop by drop of $\mathrm{HCl} 1: 1$ until the $\mathrm{pH}$ was less than 2 . N-hexane of $15 \mathrm{~mL}$ was added and shaken until homogeneous for 2 minutes. The solvent layer was gently removed through a funnel that had been covered with filter paper and 5 grams of anhydrous $\mathrm{Na}_{2} \mathrm{SO}_{4}$ which had been washed with the solvent. The remaining water phase was extracted twice with each addition of nhexane of $15 \mathrm{~mL}$. The extract was distilled at $60^{\circ} \mathrm{C}$. Furthermore, the evaporator flask containing the sample was cooled in a desiccator for 30 minutes and weighed [11].

\subsection{Total Solid Analysis}

The test sample (POME) was shaken up homogeneously, then the test sample of $5 \mathrm{~mL}$ was pipetted and put into the prepared dish. The test sample was evaporated on waterbath until the sample was dry. The test sample was put in the cup that had been evaporated into the oven at $105^{\circ} \mathrm{C}$ for 1 hour. After that, the test sample was transferred to the cup from the oven and cool in the desiccator. After 30 minutes, the test sample was weighed to obtain constant weight [12]. 


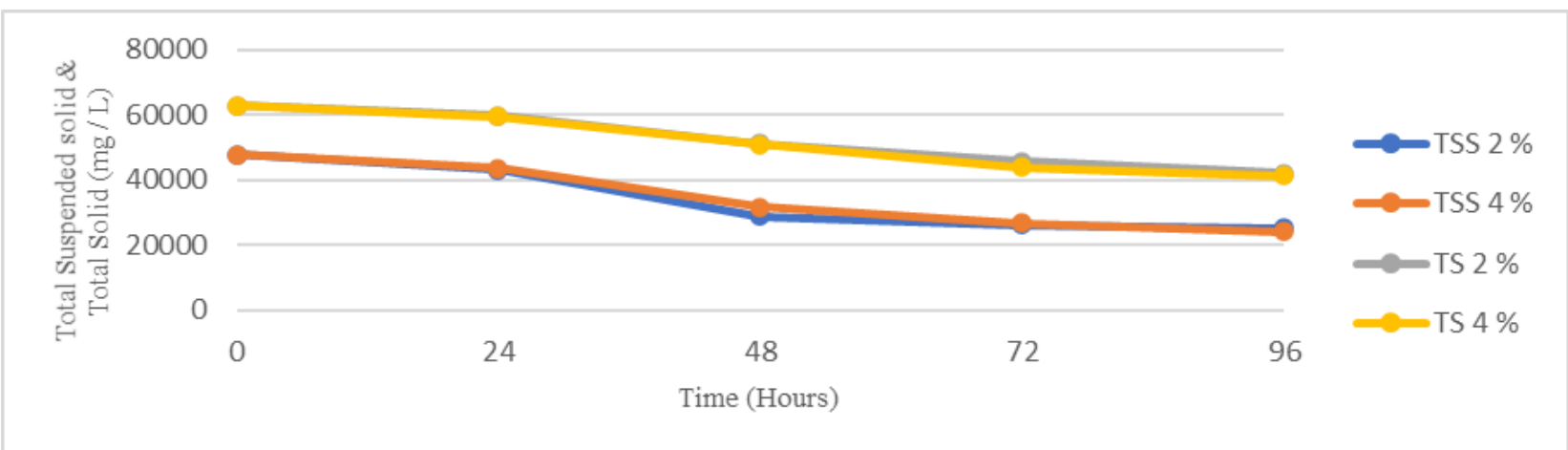

Figure 1. The decrease in total suspended solids and total solids with mixing the xylanase and lipase 2 and $4 \%$

\subsection{Reduced Sugar Analysis}

The sample of $50 \mu \mathrm{L}$ was added with $150 \mu \mathrm{L}$ DNS (3,5-dinitrosalicylic acid) and vortexed; the sample solution was heated at $100^{\circ} \mathrm{C}$ for 5 minutes and cooled in $27^{\circ} \mathrm{C}$. Mili-Q of $4800 \mu \mathrm{L}$ was added and measured at a wavelength of $540 \mathrm{~nm}$ with Uv-Vis spectrophotometer.

\subsection{Biogas Production}

A total of $133 \mathrm{~mL}$ POME from the pretreatment was put into the prepared reactor. Furthermore, POME of $259 \mathrm{~mL}$ was added with mixing xylanase and lipase of $4 \%$ concentration. It was observed for 38 days by conducting sampling, and chemical oxygen demand analysis was done. Here, the chemical oxygen demanded analysis.

\section{RESULT AND DISCUSSION}

In this study, the pretreatment of palm oil mill effluent was carried out with two variations in the concentration of xylanase and lipase, namely 2 and $4 \%$. Based on the result, it is known that the 2\% lipase activity was 27.15 unit/mL and the $4 \%$ lipase activity was 33.93 unit $/ \mathrm{mL}$. Xylanase was calculated in International Unit (IU), the amount of enzyme needed to break $1 \mu$ mol xylan into xylose released per minute under test condition. Based on the calculation, the xylanase activity with $2 \%$ concentration was 1423 unit $/ \mathrm{mL}$ and the xylanase activity with $4 \%$ concentration was $2457 \mathrm{unit} / \mathrm{mL}$.

\subsection{Pretreatment of POME using Xylanase and Lipase}

The longer the incubation time decreases the total suspended solid and the total solid. However, in a certain period of time, the decrease is not significant because the substrate is all bounded by the enzyme. It can be said that the speed of the enzymatic reaction is directly proportional to the enzyme concentration. The greater the concentration of the enzyme, the faster the reaction; and the process speed of metabolizing the

substrate complies with the enzyme concentration to obtain constant speed. Constant speed is achieved if all substrate has been bounded by the enzyme.

The figure above shows the decrease of total suspended solid and total solid. A decrease of $47.12 \%$ and $49.21 \%$ was a result of each addition of mixing xylanase and lipase concentration of 2 and $4 \%$; and the total solid decreased to $33.33 \%$ and $34.52 \%$ at concentrations of 2 and $4 \%$. The decrease in TSS and TS can be seen from the amount of the reduced sugar produced.

Figure 2 shows the percentage increase in reduced sugar because xylanase hydrolyzed hemicellulose into simple sugar. Pretreatment using xylanase can disrupt the structure of lignocellulose; in this case, hemicellulose which results in an increase in reduced sugars helps increase biogas production. The more reduced sugar produced the color becomes more reddish orange; it was based on the reaction that occurred

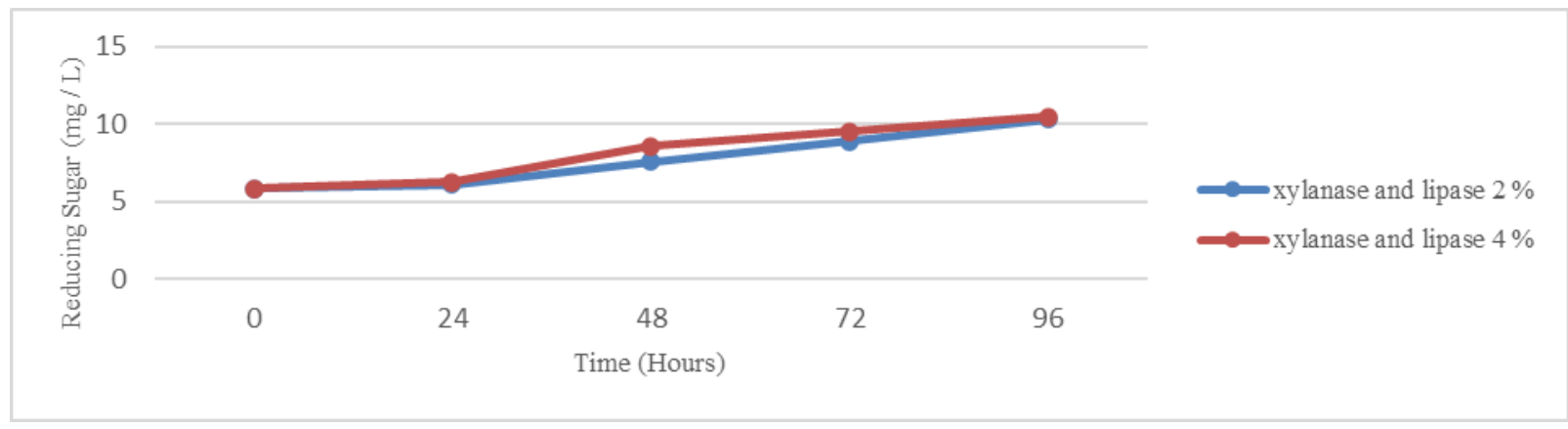

Figure 2. The increase of reduced sugar using the mixing of xylanase and lipase 2 and $4 \%$ 
between DNS and reduced sugar [8]. The use of xylanase can increase the reduced sugar by $43.50 \%$ and $44.37 \%$ in the concentration of 2 and $4 \%$, respectively, in order to increase the biogas production. Based on the result, it can be said that the more reduced sugar produced, the color becomes more reddish orange and the percentage increases.

In addition to total suspended solids and total solids, to determine the effectiveness of lipase, oil and grease measurements were carried out. Figure 3 shows the decrease with the enzyme treatment of mixed lipase and xylanase from day 1 to 5 with a decrease of $74.70 \%$ at $2 \%$ concentration and $83.53 \%$ at $4 \%$ concentration.

From the results, it can be seen that lipase can work to reduce the oil and grease content in POME. Lipase was proven to have high activity in hydrolysis reaction and in synthesis chemistry which was capable of acting as a biocatalyst for hydrolysis, esterification, alcoholysis, acidolysis and aminolysis. Lipase is a hydrolase which under aquosic condition acts on the bonds of carboxyl esters in the triacylglycerol to release fatty acid and glycerol. Triacylglycerol is a long chain that forms a natural substrate of lipase that has very low solubility in water; hydrolysis reaction occurs when fat interacts with water.

\subsection{Biogas Production}

Biogas production on a $500 \mathrm{~mL}$ volume scale had been carried out aiming to determine the effectiveness of xylanase and lipase in assisting the hydrolysis process at the POME pretreatment stage to increase biogas production. Biogas produced from anaerobic process is popular for waste treatment because the fuel produced can reduce the volume of waste. The emission of carbon dioxide produced becomes lesser and produces greater energy. In this treatment, biogas is utilized from POME by adding POME sludge with a production process for 38 days and sampling for COD analysis for 4 times. The graph below shows the result of the biogas production process with the addition of xylanase and lipase enzymes.
Based on the data above, it can be seen that there was an increase daily in biogas production. In biogas production, the addition of enzyme had a significant increase from day 0 to 38 of $230 \mathrm{~mL}$. Meanwhile, biogas production without an enzyme (xylanase and lipase) used as a control reached a production of $110 \mathrm{~mL}$. When POME was added to the enzyme, it can increase the biogas by $52.17 \%$ compared to without the addition of enzyme. It proves that hydrolysis enzyme can hydrolyze POME content, such as oil and grease, and solids which can inhibit biogas production. Thus, the enzymes help increase the biogas production process [13].

Increased biogas production can be indicated by the loss of COD content in POME. Therefore, COD analysis was carried out to determine the amount of organic matter content converted to biogas. Chemical oxygen demand is known as the amount of oxygen needed to oxidize organic substances in water sample. The measurement of chemical oxygen demand is made by making a number of standard solutions which have been known to concentrate from the analyte which determines the concentration of the sample. The standard solution used is potassium hydrogen phthalate, known as a white colored substance. The function is as a standard in the analyte gauge which is plotted on the standard curve to determine the regression value from the curve. From the calibration curve plot, it can be found that the value of $y=0,0003 x+0,0001$ with the value of the correlation coefficient (r) of 0,99673 .

From Figure 5 above, there was a decrease in COD of $49.7 \%$ which was used to calculate the amount of organic matter in wastewater and predict the potential for biogas production. The amount of oxygen equivalent to oxidizable organic matter is measured using a strong chemical oxidizer in acidic media. During the anaerobic decomposition process, the COD present in organic matter is retained to the end and converted into methane.

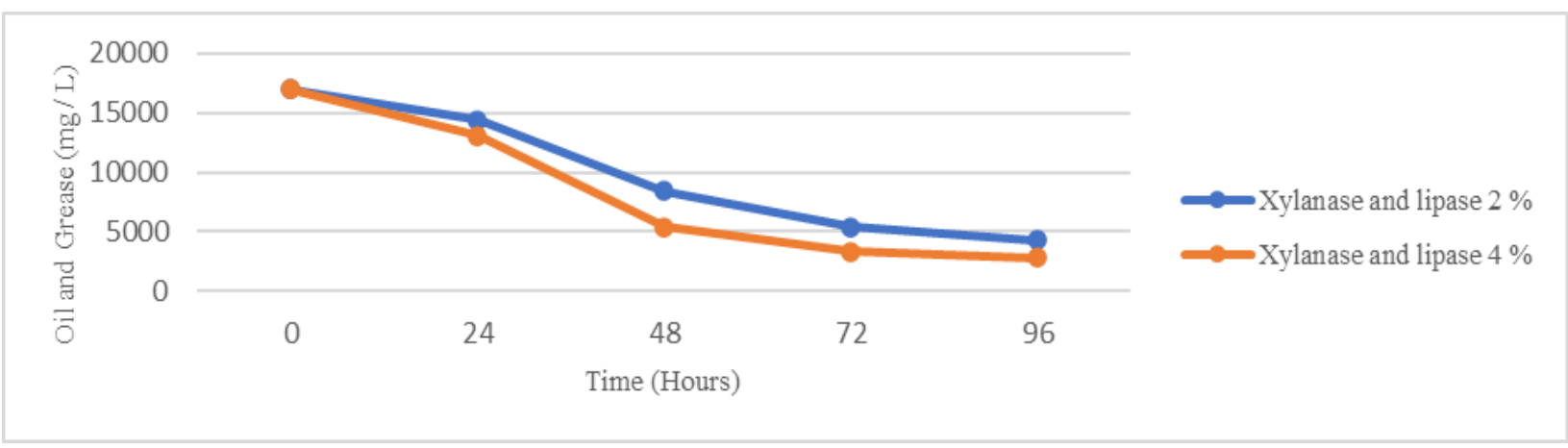

Figure 3. The decrease of oil and Grease using mixing of xylanase and lipase 2 and $4 \%$ 


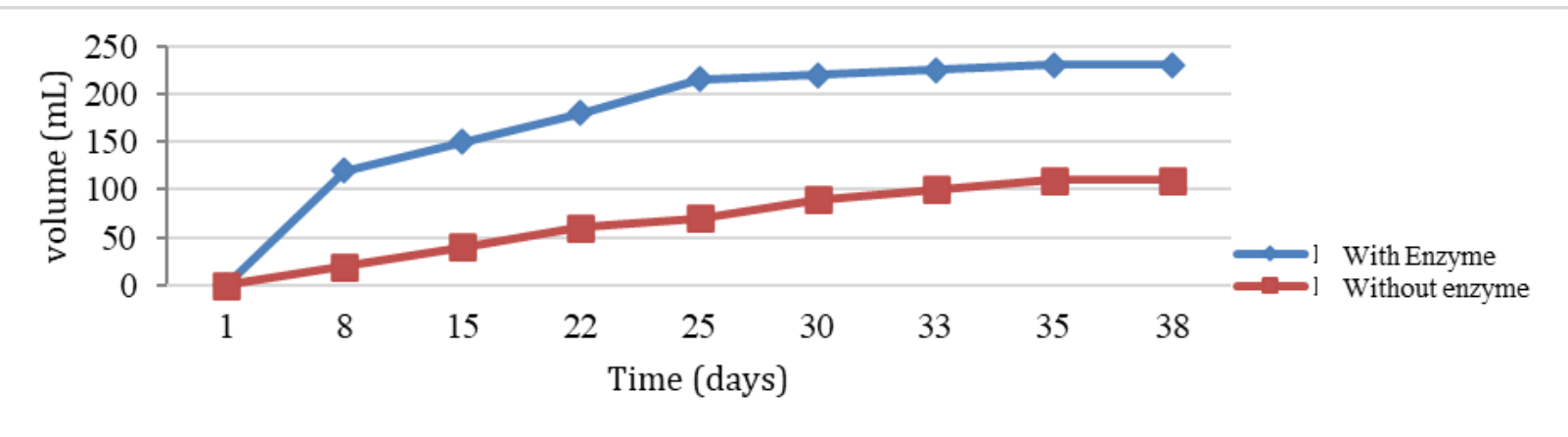

Figure 4. Biogas production with and without enzyme for 38 days

\section{CONSLUSION}

From the study, it can be concluded that pretreatment using xylanase and lipase can help hydrolyze the components present in POME. This can be proven by successfully reducing the percentage of TSS, COD, TS, and oil and fat and increasing reduced sugar. The decrease in the pretreatment of POME with xylanase and lipase occurred at a concentration of $4 \%$ by reducing TSS by $49.21 \%$; TS by $34.52 \%$, increasing reduced sugar by $44.37 \%$, and decreasing oil and grease $83.53 \%$ at $4 \%$ concentration. Pretreatment of POME with xylanase and lipase increased biogas by $52.17 \%$ and removed COD by $49.7 \%$. The expansion of pretreatment palm oil mill effluent is needed to minimize the cost production and be more economical and biogas production is a good utilization of waste because it reduces greenhouse effect and renewable source of energy.

\section{REFERENCES}

[1] Irvan. 2018. Processing of palm oil mill wastes based on zero waste technology. IOP Conference Series: Materials Science and Engineering, 309(1), 0-8. https://doi.org/10.1088/1757$\underline{899 X / 309 / 1 / 012136}$

[2] Nwuche, C. O., Aoyagi, H., \& Ogbonna, J. C. 2014. Treatment of Palm Oil Mill Effluent by a Microbial Consortium Developed from Compost Soils. International Scholarly Research Notices, 2014, 1-8. https://doi.org/10.1155/2014/762070

[3] Chin, M. J., Poh, P. E., Tey, B. T., Chan, E. S., \& Chin, K. L. 2013. Biogas from palm oil mill effluent (POME): Opportunities and challenges from Malaysia's perspective. Renewable and Sustainable Energy Reviews, 26, 717-726. https://doi.org/10.1016/j.rser.2013.06.008

[4] Khemkhao, M., Techkarnjanaruk, S., \& Phalakornkule, C. 2015. Simultaneous treatment of raw palm oil mill effluent and biodegradation of palm fiber in a high-rate CSTR. Bioresource Technology, 177, 17-27. https://doi.org/10.1016/j.biortech.2014.11.052
[5] Firoz, S. 2017. A review: Advantages and Disadvantages of Biodiesel. 530-535.

[6] Nicanuzia, J., Aparecida, J., Cruz, B., Pastore, G. M., Alimentos, D. D. C. De, Alimentos, F. D. E. De, \& Paulo, S. 2006. Characterization of Alkaline Lipase From Fusarium Oxysporum and the Effect of Different Surfactants and Detergents on the Enzyme Activity. 505-509.

[7] Prasertsan, P., Khangkhachit, W., Duangsuwan, W., Mamimin, C., \& O-Thong, S. 2017. Direct hydrolysis of palm oil mill effluent by xylanase enzyme to enhance biogas production using twosteps thermophilic fermentation under non-sterile condition. International Journal of Hydrogen Energy, 42(45), 27759-27766. https://doi.org/10.1016/j.ijhydene.2017.05.140

[8] Teixeira, R. S. S., Da Silva, A. S. A., FerreiraLeitão, V. S., \& Da Silva Bon, E. P. 2012. Amino acids interference on the quantification of reducing sugars by the 3,5-dinitrosalicylic acid assay mislead carbohydrase activity measurements. Carbohydrate Research, 363, 3337. https://doi.org/10.1016/j.carres.2012.09.024

[9] Standar Nasional Indonesia. Cara uji padatan tersuspensi (Total Suspended Solid, TSS) secara gravimetri. SNI 06-6989.3-2004

[10] Standar Nasional Indonesia. Cara uji kebutuhan Oksigen Kimiawi (Chemical Oxygen Demand (COD) dengan refluks tertutup secara spektrofotometri. SNI 6989.2:2009

[11] Standar Nasional Indonesia. Cara uji minyak dan lemak secara gravimetri. SNI 06 - 6989.10-2004

[12] Standar Nasional Indonesia. Cara uji kadar padatan total secara gravimetri. SNI 06 $6989.26-2005$

[13] Liew, Y. X., Chan, Y. J., Show, P. L., Sivakumar, M., Fong, M., Jing, Y., \& Email, C. 2015. Enzymatic Pre-treatment of Palm Oil Mill Effluent ( POME ) For Enhanced Anaerobic Digestion 1 Introduction 2 Materials and Methodology. (3133340). 